\title{
Factors Influencing Fruit Profitability at Tshakhuma and Khumbe Markets, Limpopo Province, South Africa
}

\author{
Maanda C. Dagada ${ }^{1}$, Azwihangwisi E. Nesamvuni ${ }^{1,2}$, Khathutshelo A. Tshikolomo ${ }^{1,5}$, Johan van Rooyen ${ }^{3}$ \\ \& Aldo Stroebel ${ }^{1,4}$ \\ ${ }^{1}$ Centre for Sustainable Agriculture, University of the Free State, Bloemfontein, South Africa \\ ${ }^{2}$ Office of the University Registrar, University of Venda, Thohoyamdou, South Africa \\ ${ }^{3}$ Standard Bank Centre for Agribusiness Leadership and Mentorship Development, University of Stellenbosch, \\ Stellenbosch, South Africa \\ ${ }^{4}$ National Research Foundation, Pretoria, South Africa \\ ${ }^{5}$ Limpopo Department of Agriculture, Polokwane, South Africa \\ Correspondence: Khathutshelo A. Tshikolomo, Limpopo Department of Agriculture, Private Bag X9487, \\ Polokwane, South Africa. Tel: 27-(0)-15-294-3350. Email: tshikolomo@gmail.com
}

Received: March 22, 2015 Accepted: April 23, 2015 Online Published: June 15, 2015

doi:10.5539/jas.v7n7p53 URL: http://dx.doi.org/10.5539/jas.v7n7p53

\begin{abstract}
The purpose of the study was to investigate the factors influencing profitability of fruits sold at Tshakhuma and Khumbe Markets in Limpopo Province of South Africa. Some 91 market operators were interviewed, 67 from Tshakhuma and 24 from Khumbe Market. Fruit profitability was influenced by: (1) method of acquisition of the fruits by market operators (own production vs other sources); (2) expenditure on fruit acquisition (increased spending resulted in loss of profit); (3) fruit storage (increased storage resulted in loss of profit), and (4) use of the cooperative approach (associated with increased profit). Socio-economic characteristics of market operators also influenced profitability of sold fruits. The characteristics for market operators were described in terms of: (a) gender, where majority of operators $(91.2 \%)$ were women, (b) age with $80 \% \leq 60$ years old and (c) household size that were mostly large (6-7 persons) and provided for family labour. Low levels of education necessitate training for increased fruit profitability.
\end{abstract}

Keywords: market, operator, produce, profit, Tshakhuma, Khumbe, Vhembe District, Limpopo Province, South Africa

\section{Introduction}

Present trade, marketing and institutional policies in South Africa make limited provision for unique interests of emerging smallholder farmers. Furthermore, the current institutions involved in promoting market access are not well co-ordinated. Constraints to market access can be addressed through a combination of public intervention and private sector involvement. Kwaw (2006) stated that on the local market, small-scale income generation projects continue to face tough competition with established chain stores selling similar products to those that are the main focus of community projects. In the same article Kwaw pointed to the fact that efforts to reach the local market with their products are hampered by the better quality of product, competitive pricing, and better packaging of chain stores.

Lyne (1996) and Matungul et al. (2001) as cited by Ortmann and King (2007) indicated that Small-scale farmers in South Africa, as in other developing countries, have limited access to factors of production, credit and information; and markets are often constrained by inadequate property rights and high transaction costs. This further illustrates the difficulties that farmers have in accessing market for their products. It is however, true that increased subsistence production has the potential to improve the food security of poor households in both rural and urban areas by increasing food supply, and by reducing dependence on purchasing food in a context of high food price inflation, but the efficiency of marketing and distribution systems, household purchasing patterns, ability to produce own food (Baiphethi \& Jacobs, 2009).

It cannot be disputed that the participation of small farmers in markets is, therefore, important for pro-poor rural 
development at the same time access to attractive markets is also often the spur for increased production and the adoption of new technologies (van der Heijden \& Vink, 2013). As much as farmers can have capacity to increase their production, the fact remains rural poor people feels that one reason they cannot improve their living standards is that they face difficulties in accessing markets (IFAD, 2003; van der Heijden \& Vink, 2013). As Mwale et al. (2012) puts it, Markets need products in bulk which the community project members may not be able to meet.

Makhura and Mokoena (2003) identified potential solutions that include overcoming infrastructure backlogs, improving market information, institutional reform (such as promoting a land rental market) and supporting smallholder food processing and value adding. Most of these market are informal and "there has been an apparent renewed interest in informal markets and it is increasingly being recognised that informal markets are important indicators of the political and economic health of a society" (Vermaak, 2014). Emerging markets such as Tshakhuma and Khumbe Market in Limpopo Province provide farmers with an important opportunity to sell their produce. Continued operation of these markets depends on the profitability of the produce sold. This study was conducted to investigate (1) the types and sources of produce sold in the markets under study and (2) factors influencing the profitability of the produce and possible correlations among them. The investigation was aimed at providing useful information to guide investment decisions on marketing of the produce.

\section{Research Methodology}

\subsection{Description of Study Area}

The study was conducted in the Limpopo Province of South Africa and was focused on the Vhembe District Municipality of the province. The Limpopo Province constitutes the northern part of South Africa forming borders with Botswana in the north-west, Zimbabwe in the north and through the Kruger National Park forms border with Mozambique in the east. Within South Africa, the province forms border with Mpumalanga Province in the south-east, Gauteng in the south and the North-West Province in the south-west (Office of the Premier [OTP], 2009).

In order to gain a comprehensive understanding of the market challenges, the study provided a specific focus on the Tshakhuma Market in Makhado and the Khumbe Market in Thulamela Local Municipality (Figure 1).



Figure 1. Map of the study area showing the location of the Tshakhuma Market in the Makhado Municipality and the Khumbe Market in the Thulamela Municipality in Vhembe District (LDA, 2014)

The Tshakhuma Market is located closer to the commercial Levubu farms and would therefore be expected to acquire produce for selling from not only the surrounding smallholder farmers, but also the nearby commercial 
farmers. The Khumbe Market is located deep in a rural settlement and would likely acquire produce for selling from surrounding households and small-scale emerging farmers.

\subsection{Sampling Frame and Sampling Procedure}

A sampling frame was described by Lohr (2010) as a list, map, or other specification of sampling units in the population from which a sample may be selected. The importance of a sampling frame in scientific research was shown by Welman, Kruger and Mitchell (2005) who indicated that it is impossible to properly judge the representativeness of the obtained sample unless a sampling frame is borne in mind. A representative sample is a requirement for the research results to be credible and trustworthy (Leedy \& Ormrod, 2010). Although sample representativeness is necessary, there are instances where less representative purposive samples are valuable.

Multistage sampling was conducted as described by Leedy and Ormrod (2010) and involved (1) primary area selection of municipalities (both district and local municipalities), (2) location selection of agricultural markets and (3) respondent selection of stakeholders sampled for interviews. In accordance with the guidelines by Leedy and Ormrod (2010), the sampling for this study included representative random sampling and less representative purposive sampling.

For primary area selection of municipalities, the sampling frame was composed of the five district municipalities of the Limpopo Province, namely: Vhembe, Capricorn, Mopani, Sekhukhune and Waterberg District Municipality, and the Vhembe District was purposively sampled for its accessibility to the researcher. At a local municipality level, four municipalities of the selected Vhembe District comprised the sampling frame, namely: Thulamela, Makhado, Musina and Mutale Local Municipality. The Thulamela Municipality was also purposively sampled for its accessibility to the researcher as he resided in the municipality while the Makhado Municipality was purposively included for being a large producer of sub-tropical fruits.

As for location selection, the sampling frame was comprised of numerous agricultural markets of various sizes (with or without shelter infrastructure). The Tshakhuma Market was purposively sampled for its location near a major commercial farming area (Levubu farms) while the Khumbe Market was selected for its location in the midst of small-scale emerging farmers. The Tshakhuma Market would address market challenges of both the surrounding smallholder and the nearby commercial farmers while the Khumbe Market would mainly address challenges of the surrounding smallholder farmers.

As indicated for a related study by Dagada, Nesamvuni, Van Rooyen and Tshikolomo (2013), the sampling frame for market operators comprised of 600 members for Tshakhuma and 200 for Khumbe Market. Some 67 market operators were randomly sampled for Tshakhuma while 24 were randomly selected for the Khumbe Market.

\subsection{Data Collection and Analysis}

Primary data was collected from the sampled respondents through interviews which were conducted by trained enumerators using a structured questionnaire. The questionnaire contained both open- and closed-ended questions which included issues of market challenges and the strategies used by farmers to address the challenges. The closed-ended questions collected quantitative data while the open-ended questions recorded qualitative data (Leedy \& Ormrod, 2010).

The inclusion of open-ended questions that recorded qualitative data was to enable respondents to speak for themselves, voice the constraints they faced, articulate their own accounts of what their routines were and how they satisfied their needs (Tshikolomo, Nesamvuni, Stroebel, \& Walker, 2012). As was stated by the Food and Agriculture Organization of the United Nations [FAO] (2001), qualitative techniques were directed towards improved understanding of the market challenges experienced by the farmers as influenced by their socio-cultural environment. This research method that combines the collection and analysis of quantitative data with that of qualitative data is referred to as a mixed study (Hurmerinta-Peltomaki \& Nummela, 2006). The questionnaire was complemented by an interview guide for a focus group and interview schedules for several key informants, and these collected qualitative data.

Some primary data was also collected through observations. The data collected through observation was mainly that of types of fruits sold at the two markets and types of fruits produced through own production by the households of market operators. Secondary data was collected by studying relevant documents, reports and other literature.

Data collected was analyzed using a Statistical Package for Social Sciences version 11(SPSS). Correlation and regression coefficients of different variables were computed to establish their influence on profitability of produce sold in the study markets. Quantitative data was objectively interpreted while qualitative data was subjectively interpreted. 


\section{Results}

In accordance with the purpose of the study, the results are discussed in terms of (1) the types and sources of produce sold in the markets and (2) factors influencing the profitability of the produce and possible correlations among them.

\subsection{Types and Sources of Produce Sold in the Study Markets}

\subsubsection{Types of Produce Sold in the Study Markets}

The profitability of produce sold by market operators is influenced by the types of produce and the sources from which they were acquired. The types of produce sold in the markets were influenced by such factors as the demand, supply, and subsequent prices of those produce.

The produce sold in the Tshakhuma and Khumbe markets were observed to be mostly (a) subtropical fruits such as pawpaws, mangoes, bananas, avocadoes, and litchis and (b) citrus fruits such as oranges and tangerines. Limited quantities of other agricultural produce such as vegetables were also sold. Fruits were the major produce sold in the markets under study and were therefore the focus of this investigation.

\subsubsection{Sources of Fruits Sold in the Markets}

The sources from which the fruits were acquired were influenced by their associated costs and this would in turn influence the market price of the fruits. The costs of acquisition of fruits were influenced by such factors as the production and transport costs for delivery to the market. The study revealed that different sources were used to acquire various types of fruits, both subtropical (pawpaw, mango, banana, avocado and litchi) and citrus (orange and tangarine) fruits (Table 1).

\section{(a) Sources of Subtropical Fruits}

Based on rating by market operators, the most important source of pawpaws was own production followed by acquisition from smallholder farmers and last acquisition from commercial farmers. A large number of households in the study area were observed to have fruit trees in their residential sites and these included pawpaw trees. Pawpaws were also mostly included among fruit trees owned by smallholder fruit producers in the area. The rating of own source as most important for supply of pawpaws to the study markets resulted from the fact that the fruit trees were planted by many households, and accordingly smallholder farmers were the second most important source.

Table 1. Sources of major fruits sold at Tshakhuma and Khumbe Markets and their level of importance based on rating by market operators

\begin{tabular}{lllll}
\hline \multirow{2}{*}{ Type of subtropical fruit } & \multicolumn{4}{c}{ Source and frequency rating } \\
\cline { 2 - 5 } & Own production & Smallholder & Commercial & Hawker \\
\hline Pawpaw & 1 & 2 & 3 & $\mathrm{~N}$ \\
Mango & 3 & 2 & 4 & 1 \\
Banana & 3 & 4 & 1 & 2 \\
Avocado & 1 & 2 & 3 & 4 \\
Litchi & $\mathrm{N}$ & 1 & 2 & $\mathrm{~N}$ \\
Citrus & & & & \\
Orange & 4 & 3 & 1 & 2 \\
Tangarines & 3 & 4 & 1 & 2 \\
\hline
\end{tabular}

Note. 1 = Most important, source used by most market operators; 4 = Least important, source used by least market operators; $\mathrm{N}=$ Unused, source not used by any market operator.

The most important source of mangoes were hawkers followed by smallholder farmers, then own production and last commercial farmers. Although most households had mango trees in their residential sites, those were mostly indigenous varieties with large seed, lot of fibre and sometimes sour taste and were less liked by consumers. As a result, the market operators mostly bought mangoes from hawkers who sold modern cultivars acquired from commercial farmers followed by those who bought the fruit from smallholder farmers as they were mostly also 
planting modern cultivars. Direct acquisition of mangoes from commercial farmers was probably restricted by lack of transport as the fruit is less produced in nearby portions of Levubu Farms and most of the mango farmers were located away from the study area.

As for bananas, the most important source from which the fruit was acquired by market operators was commercial farmers followed by hawkers, then own production and last smallholder farmers. Bananas were abundantly produced in the nearby commercial Barrota and Levubu Farms and these were likely the major sources of the fruit to the study markets. Hawkers probably also bought the bananas from those nearby commercial farms.

As was the case with pawpaws and mangoes, most households in the study area had avocado trees in their residential sites. The varieties of avocadoes produced by the households largely included modern cultivars, and contrary to the situation with mangoes, the indigenous varieties were relatively more accepted by consumers; hence own production constituted the most important source of avocado fruit to market operators. For similar reasons, smallholder farmers were the second most important source of avocadoes and commercial farmers only came third and hawkers had no business opportunity as there was abundant supply locally. Litchis were mostly sourced from smallholder and from commercial farmers. The subtropical fruits were coordinated under specific commodity associations affiliated to the Subtropical Growers Association (Subtrop) and these had different levels of strengths for coordination.

\section{(b) Sources of Citrus Fruits}

The most important source of citrus fruits (oranges and tangerines) was commercial farmers followed by hawkers who mostly bought the fruits from the commercial farmers, and this was because production of these fruits by local households and smallholder farmers was limited. Also, the citrus commodity seemed to be well coordinated under the Citrus Growers Association and therefore smallholder farmers producing citrus found it relatively easier to become commercial.

\subsection{Factors Influencing Profitability of Fruits Sold at the Markets}

In investigating the factors influencing the profitability of fruits sold at the Tshakhuma and Khumbe Market, the study considered (1) the socio-economic characteristics of market operators and (2) the factors that were closely linked to the operation of the market business.

\subsubsection{Socio-Economic Characteristics of Market Operators}

Analysis of the characteristics of human beings as participants in a development process is essential for successful community development (Crounch \& Camala, 1981). Other than the factors discussed above, the profitability of fruits sold at the Tshakhuma and Khumbe Market is influenced by characteristics of market operators, and those include gender, age, education and size of household.

\section{(a) Gender}

Gender plays an important role in development and would therefore influence the profitability of fruits sold at the markets. As stated by Bembridge and Tshikolomo (1998), decision making among fruit growers in the Phaswana area was male dominated with women mainly focussing on decision implementation.

Table 2. Distribution of respondents in the Khumbe and Tshakhuma markets according to sex of heads of household

\begin{tabular}{|c|c|c|c|c|c|c|}
\hline \multirow{3}{*}{ Name of the market } & \multicolumn{4}{|c|}{ Sex of head of household } & \multirow{2}{*}{\multicolumn{2}{|c|}{ Total no of households }} \\
\hline & \multicolumn{2}{|c|}{ Male } & \multicolumn{2}{|c|}{ Female } & & \\
\hline & $\mathrm{N}$ & $\%$ & $\mathrm{~N}$ & $\%$ & $\mathrm{~N}$ & $\%$ \\
\hline Tshakhuma & 32 & 47.8 & 35 & 52.2 & 67 & 100 \\
\hline Khumbe & 14 & 58.3 & 10 & 41.7 & 24 & 100 \\
\hline Total & 46 & 50.5 & 45 & 49.5 & 91 & 100 \\
\hline
\end{tabular}

Of the 91 market operators selected for the study (67 from Tshakhuma and 24 from Khumbe Market), about one in ten $(8.8 \%)$ were male and nine in ten $(91.2 \%)$ female. All male market operators were found at Khumbe Market, a situation that suggest that operators in that market could also have provided other services that 
necessitated characters of men, e.g. security and farming to supply the market. Market operators at the Tshakhuma Market mostly bought produce from large commercial Levubu farmers who are focused in their farming business and could not possibly have served as operators, hence the operators in this market were all female. The results suggest that the job of market operation in the study area was largely regarded a responsibility for women (Dagada et al., 2013). Contrary to the situation with men, women would likely keep their fruits well packed and clean and would therefore attract more buyers, and this would make the fruits more profitable.

(b) Age

The age of an individual is one of the most important factors that determine the way he or she thinks and behaves. The types of decisions made by elderly people and their ways of behaving tend to be different from those of their younger counterparts.

Table 3. Distribution of respondents in the Khumbe and Tshakhuma markets according to age

\begin{tabular}{|c|c|c|c|c|c|c|}
\hline \multirow{2}{*}{ Age category (years) } & \multicolumn{2}{|c|}{ Tshakhuma Market } & \multicolumn{2}{|c|}{ Khumbe Market } & \multicolumn{2}{|c|}{ Combined } \\
\hline & $\mathrm{N}$ & $\%$ & $\mathrm{~N}$ & $\%$ & $\mathrm{~N}$ & $\%$ \\
\hline $0-18$ & 1 & 1.5 & 0 & 0.0 & 1 & 1.1 \\
\hline $19-20$ & 1 & 1.5 & 1 & 4.2 & 2 & 2.2 \\
\hline $21-30$ & 11 & 16.4 & 5 & 20.8 & 16 & 17.6 \\
\hline $31-40$ & 17 & 25.4 & 3 & 12.5 & 20 & 22.0 \\
\hline $41-50$ & 19 & 28.4 & 1 & 4.2 & 20 & 22.0 \\
\hline $51-60$ & 12 & 17.9 & 2 & 8.3 & 14 & 15.4 \\
\hline $61+$ & 6 & 9.0 & 12 & 50.0 & 18 & 19.8 \\
\hline Total & 67 & 100.0 & 24 & 100.0 & 91 & 100.0 \\
\hline
\end{tabular}

Some $1.1 \%$ of the respondents were at most 18 years old while some $2.2 \%$ were in the age group of 19 to 20 years old, and this comprised of $1.5 \%$ for Tshakhuma and $4.2 \%$ for Khumbe Market (Table 3). The fact that 17.6 $\%$ of the respondents (16.4\% for Tshakhuma and 20.8\% for Khumbe Market) were in the age group of 21-30 reveals that youth in the study area do participate in agriculture at the marketing level of the value chain. Also, one in five $(22.0 \%)$ of the respondents were aged 31-40 years old, and this confirmed participation of youthful members of the study community in the marketing of agricultural produce. The respondents in this age category comprised one in four (25.4\%) for the Tshakhuma and one in eight (12.5\%) for the Khumbe Market.

The same number $(22.0 \%)$ of respondents was in the middle ages of $41-50$ years old with more $(28.4 \%)$ for Tshakhuma and fewer (4.2\%) for Khumbe Market. Relatively fewer (15.4\%) respondents were in their elderly ages of 51-60 years old comprised of 17.9\% for Tshakhuma and 8.3\% for Khumbe Market. Also, one in five $(19.8 \%)$ of the respondents were over 60 years $(9.0 \%$ for Tshakhuma and $50.0 \%$ for Khumbe Market) and this would include those in pension.

As mentioned by Bembridge, Graven, Hough, and Van Rooyen (1982), although increasing age may have an impairing effect on the physical ability of participants, several research studies indicated little or no mental deterioration at least up to sixty years of age. Since marketing and its management is considered primarily to be a mental process, it is assumed that at least up to the age of sixty, managerial ability will not be seriously impaired. It may therefore be concluded that approximately $80 \%$ of the respondents ( $\leq 60$ years of age) in the two markets had necessary mental capacity to carry out their operation efficiently and to make profits.

\section{(c) Education}

As stated by Ndegwe, Mureithi, and Green (1985), education is a basic need in its own right, a way of meeting other basic needs, and an activity that sustains and accelerates overall development. This statement was affirmed by Olaiton (1984) and Tompson (1981) who indicated that more years of schooling are associated with higher rates of adoption of innovations than are fewer years of schooling.

About one in five $(22.0 \%)$ of the market operators had no schooling, and this comprised of $22.4 \%$ for Tshakhuma and $20.8 \%$ for Khumbe Market (Table 4$)$. Some $2.2 \%$ of the market operators $(3.0 \%$ for Tshakhuma 
and none for Khumbe Market) reportedly passed grades $1-3$, up to $12.1 \%$ (11.9\% for Tshakhuma and $12.5 \%$ for Khumbe Market) passed grades $4-5$ while $11.0 \%$ (10.4\% for Tshakhuma and $12.5 \%$ for Khumbe Market) passed grades 6-7 and these are primary school grades. The market operators with primary education (or none) constituted $47.3 \%$ and probably had none to low literacy and numeracy skills with those who attained higher grades (grades 4-5 and 6-7) possibly having achieved basic levels of these skills.

Table 4. Distribution of market operators in the Khumbe and Tshakhuma markets according to level of education

\begin{tabular}{|c|c|c|c|c|c|c|}
\hline \multirow{2}{*}{ Level of education } & \multicolumn{2}{|c|}{ Tshakhuma Market } & \multicolumn{2}{|c|}{ Khumbe Market } & \multicolumn{2}{|c|}{ Combined } \\
\hline & $\mathrm{N}$ & $\%$ & $\mathrm{~N}$ & $\%$ & $\mathrm{~N}$ & $\%$ \\
\hline No schooling & 15 & 22.4 & 5 & 20.8 & 20 & 22.0 \\
\hline Grade 1-3 & 2 & 3.0 & 0 & 0.0 & 2 & 2.2 \\
\hline Grade 4-5 & 8 & 11.9 & 3 & 12.5 & 11 & 12.1 \\
\hline Grade 6-7 & 7 & 10.4 & 3 & 12.5 & 10 & 11.0 \\
\hline Grade 8-9 & 5 & 7.5 & 4 & 16.7 & 9 & 9.9 \\
\hline Grade $10-11$ & 14 & 20.9 & 4 & 16.7 & 18 & 19.8 \\
\hline Grade 12 & 9 & 13.4 & 4 & 16.7 & 13 & 14.3 \\
\hline Diploma & 7 & 10.4 & 1 & 4.2 & 8 & 8.8 \\
\hline Total & 67 & 100.0 & 24 & 100.0 & 91 & 100.0 \\
\hline
\end{tabular}

One in ten $(9.9 \%)$ of the market operators $(7.5 \%$ for Tshakhuma and $16.7 \%$ for Khumbe Market) had passed grades $8-9$, two in ten (19.8\%) of them (20.9\% for Tshakhuma and $16.7 \%$ for Khumbe) had passed grades $10-11$, while $14.3 \%$ of the market operators (13.4\% for Tshakhuma and $16.7 \%$ for Khumbe Market) had passed Grade 12. The market operators with secondary education constituted $44.0 \%$ and would have better literacy and numeracy skills than those with only primary education.

Only $8.8 \%$ of the market operators $(10.4 \%$ for Tshakhuma and $4.2 \%$ for Khumbe Market) had completed diplomas. These market operators acquired high levels of competencies in their fields of study and could be under-utilized by working as market operators. The market job for this category of operators could have been taken as interim responsibilities while they search for preferred jobs aligned to their diploma qualifications. Some of these market operators might even be performing the market job as complementary while also involved in some other jobs where their competencies are fully utilized. The market operators with higher education levels were probably those that had other incomes and were able to make profits in their sales of fruits.

\section{(d) Household Size}

Many factors act together to determine the size of a household, and those include access to information on family planning services, family income, maternal and child health care, women's status in society, level of education, religious and cultural factors. Although larger households would have advantage of providing more labour, they also cause great financial burdens which affect the family's ability to finance development initiatives (Williams, 1986). Rural areas are characterized by occurrence of extended families that tend to make the households rather large. The extended family, according to Goodman and Marx (1978), consists of several nuclear families united by parent-child relationships and living together either in the same house or in a compound. The market operators in the area under study reported large families of an average of 6 members for Tshakhuma and 7 members for Khumbe Market (Dagada et al., 2013).

Most of the households involved in market activities used their own family members with only $1.5 \%$ of those working at the markets being hired labour. From the informal discussions with the participants in the two markets, it became apparent that hired labour had become too expensive for households to afford. The large families of market operators made it possible for some household members to be assigned the responsibilities of selling the produce at the market, and this made the business more profitable as otherwise expensive labour did not have to be hired.

\subsubsection{Factors Linked to the Operation of the Market Business}

The market linked factors that influenced profitability of the fruits sold were fruits that were own produced, 
expenditure on fruit acquisition, fruits wasted, fruits consumed, other household income, fruit storage and belief in cooperative approach. Analyses of these factors were based on (a) regression coefficients showing the extent to which the factors determined profitability of fruits sold and (b) correlation coefficients for various pairs of the factors.

\section{(a) Regression Analysis of the Extent to Which the Factors Determined Profit}

As shown by the regression coefficient (Table 5), reduction of expenditure on fruits resulted in increased profits $(\mathrm{p}<0.05)$. Also, profit seemed to be determined by the ability of market operators to produce their own fruits ( $p$ $<0.01)$. This was mainly because own production by market operators had lesser costs. The costs incurred would normally be those of production inputs such as seedlings, fertilizers and pesticides. It was observed that market operator and other households in the study area were able to produce their own seedlings from seeds of selected varieties, and this reduced the cost of production of the fruits sold at the markets. Households that could not produce their own seedlings were able to buy from neighbours and from nearby small nurseries at highly reduced prices.

Also, households in the study area mostly relied on plant materials and application of manures for improving their soil fertility and did not have to buy fertilizers. The plant materials and manures were mostly locally freely available, and this further reduced the cost of own production of fruits. Own production was at very small scale and therefore families involved used own labour, and this further reduced the cost of production. Households that hired labour also used it for chores other than production of the fruits.

Although the market operators identified only pawpaws and avocadoes to be mostly supplied from own production, the source also served as third most important for mango, banana, and tangarines and was least important for oranges (Table 1). The contributions of market operator fruits that were own produced to profitability of items sold at the study markets were therefore important.

Table 5. Regression coefficients of business linked determinants of fruit profits in the Tshakhuma and Khumbe Markets

\begin{tabular}{lll}
\hline Variable & Standardised coefficient Beta $(\boldsymbol{\beta})$ & Significance level \\
\hline Fruits wasted & 0.023 & 0.876 \\
Expenditure on fruit & -0.098 & 0.021 \\
Fruits own produced & 0.817 & 0.0001 \\
Cooperative approach & 0.086 & 0.064 \\
Fruit consumed & 0.085 & 0.623 \\
Other income & -0.020 & 0.641 \\
Fruit storage & -0.110 & 0.018 \\
\hline
\end{tabular}

Availability of storage facilities would allow for the items to be stored when the supply to the market is abundant and released when the supply is scarce. The prospect for a storage facility in the study area was associated with reduced profits $(p<0.05)$, a situation that could be attributable to (1) high costs of refrigeration to maintain the quality of the fruits or (2) quality deterioration in the storage resulting in sales at reduced prices or complete disposal.

Although a cooperative approach would easily be recommended for small businesses in the study area, it did not emerge as an important issue for the markets under study (Table 2). The less regard for a cooperative suggests that market operators would rather work as individuals than a cooperative. A detailed investigation on the prospect of establishing a market operator cooperative would be necessary to fully understand the rational for the respondents not considering it important.

\section{(b) Correlations among Business Linked Factors Determining Fruit Profits}

The effect of identified factors on profitability of fruits sold at the Tshakhuma and Khumbe Markets might probably also be influenced by interactions among those factors. It is for this reason that the study also assessed the correlations between pairs of factors that were considered to determine the profitability of fruits sold at the two markets (Table 3). 
There was a strong positive correlation $(\mathrm{r}=0.883 ; \mathrm{p}<0.01)$ between fruits that were own produced and those wasted. The market operators that produced their own fruits had low input costs and could therefore afford to waste some of the fruits, and this resulted in more wastage when own production increased. A rather low negative correlation $(\mathrm{r}=-0.236 ; \mathrm{p}<0.05)$ was noted between cooperative approach and fruit wastage, suggesting that market operators believing in cooperative approach had lesser fruits wasted. The market operators believing in cooperative approach would therefore be more efficient and profitable.

Table 6. Correlations among business linked variables determining fruit profits at the Tshakhuma and Khumbe Markets

\begin{tabular}{|c|c|c|c|c|c|c|c|c|}
\hline Major Variables & $\begin{array}{l}\text { Fruits } \\
\text { wasted }\end{array}$ & $\begin{array}{l}\text { Expenditure } \\
\text { on fruit }\end{array}$ & $\begin{array}{l}\text { Fruits own } \\
\text { produced }\end{array}$ & $\begin{array}{l}\text { Coop } \\
\text { approach }\end{array}$ & $\begin{array}{l}\text { Fruit } \\
\text { consumed }\end{array}$ & $\begin{array}{l}\text { Other } \\
\text { income }\end{array}$ & $\begin{array}{l}\text { Fruit } \\
\text { storage }\end{array}$ & Profit \\
\hline Fruit wasted & 1.000 & $\begin{array}{l}0.059 \\
(0.293)\end{array}$ & $\begin{array}{l}0.883 \\
(0.000)\end{array}$ & $\begin{array}{l}-0.236 \\
(0.014)\end{array}$ & $\begin{array}{l}0.961 \\
(0.000)\end{array}$ & $\begin{array}{l}-0.043 \\
(0.345)\end{array}$ & $\begin{array}{l}-0.269 \\
(0.006)\end{array}$ & $\begin{array}{l}0.046 \\
(0.335)\end{array}$ \\
\hline Expenditure on fruit & & 1.000 & $\begin{array}{l}0.085 \\
(0.214)\end{array}$ & $\begin{array}{l}-0.104 \\
(0.167)\end{array}$ & $\begin{array}{l}0.057 \\
(0.298)\end{array}$ & $\begin{array}{l}0.022 \\
(0.421)\end{array}$ & $\begin{array}{l}-0.090 \\
(0.202)\end{array}$ & $\begin{array}{l}-0.180 \\
(0.047)\end{array}$ \\
\hline Fruit own produced & & & 1.000 & $\begin{array}{l}-0.293 \\
(0.003)\end{array}$ & $\begin{array}{l}0.912 \\
(0.000)\end{array}$ & $\begin{array}{l}-0.111 \\
(0.152)\end{array}$ & $\begin{array}{l}-0.281 \\
(0.004)\end{array}$ & $\begin{array}{l}-0.023 \\
(0.414)\end{array}$ \\
\hline Coop approach & & & & 1.000 & $\begin{array}{l}-0.235 \\
(0.014)\end{array}$ & $\begin{array}{l}0.232 \\
(0.015)\end{array}$ & $\begin{array}{l}0.328 \\
(0.001)\end{array}$ & $\begin{array}{l}0.063 \\
(0.280)\end{array}$ \\
\hline Fruit consumed & & & & & 1.000 & $\begin{array}{l}-0.070 \\
(0.258)\end{array}$ & $\begin{array}{l}-0.290 \\
(0.003)\end{array}$ & $\begin{array}{l}0.044 \\
(0.341)\end{array}$ \\
\hline Other income & & & & & & 1.000 & $\begin{array}{l}0.250 \\
(0.010)\end{array}$ & $\begin{array}{l}0.212 \\
(0.023)\end{array}$ \\
\hline Fruit storage & & & & & & & 1.000 & $\begin{array}{l}0.130 \\
(0.115)\end{array}$ \\
\hline Profit & & & & & & & & 1.000 \\
\hline
\end{tabular}

A negative correlation $(\mathrm{r}=-0.293 ; \mathrm{p}<0.01)$ was also recorded between cooperative approach and fruit own produced and this suggested that the market operators who believed in a cooperative approach were less reliant on own production. The strong positive correlation between fruit consumed and that wasted $(\mathrm{r}=0.961 ; \mathrm{p}<0.01)$ suggests that market operators who consumed more of the fruit also wasted more of it. The market operators who consumed more of the fruits were mostly involved in own production $(\mathrm{r}=0.912 ; \mathrm{p}<0.01)$, had less belief in a cooperative approach $(\mathrm{r}=-0.235 ; \mathrm{p}<0.05)$, and were probably less profitable.

The positive correlation between other income and cooperative approach $(r=0.232 ; \mathrm{p}<0.05)$ indicates that market operators who believed in a cooperative approach also had other sources of income, suggesting that they were involved in other income generating activities. These were probably the operators who had higher levels of education, were demanded by other sectors and would likely be more efficient in their businesses.

It was interesting to note that fruit storage was negatively correlated with factors such as fruit wastage ( $\mathrm{r}=$ $-0.269 ; \mathrm{p}<0.01)$, fruit own produced $(\mathrm{r}=-0.281 ; \mathrm{p}<0.01)$ and fruit consumed $(\mathrm{r}=-0.290 ; \mathrm{p}<0.01)$ while positively correlated with belief in a cooperative approach $(r=0.328 ; p<0.01)$ and other income $(r=0.250 ; p<$ 0.05). The results implied that market operators with fruit storage had less wastage as unsold items could be stored and sold the next day. The fact that operators with storage were less involved in fruit own production suggests that storage was more important where the produce was procured (probably in bulk) from other areas. The operators who produced own fruits probably had less need for storage as small amounts of fruits could be picked for daily sales while the rest is left on the trees, at least for some days. The positive correlation between fruit storage and belief in a cooperative approach suggests that the operators with storage were aware of the benefits of a cooperative approach to their business as this would allow for bulk procurement and storage where the costs would be reduced thereby increasing their chances of making profit. These operators with fruit storage mostly had other incomes and were economically well off compared to their counterparts.

The main determinants of profits were expenditure and availability of other income. An increase in the spending of market operator households resulted in lower profits $(r=-0.180 ; p<0.05)$ while availability of other income 
resulted in more profit $(\mathrm{r}=0.212 ; \mathrm{p}<0.05)$. The increased spending would probably be that on acquisition of fruits, e.g. the spending on procurement and on transportation of the fruits for sale at the markets. Availability of other income would, for instance enable operator households to buy own car and spend less on transport of the fruits from places where they were bought and to market as opposed to relying on local entrepreneurs for hiring of transport.

\section{Conclusion}

The fruits sold at the Tshakhuma and Khumbe markets were mainly (1) subtropical fruits such as pawpaw, mango, banana, avocado and litchi, and (2) citrus fruits such as oranges and tangerines. Market operators acquired the fruits from combinations of sources, and those were mainly own production, hawkers, smallholder and commercial farmers.

Factors that influenced the profitability of the fruits sold were (1) socio-economic characteristics of market operators and (2) factors linked to the operation of the market business. Considering socio-economic characteristics of market operators, fruit profitability would likely be enhanced for (i) nine in ten (91.2\%) of the operators who were women, (ii) four in five $(80 \%)$ who were $\leq 60$ years old and (iii) majority of operator households that were large (6-7 persons) and allowed for family labour. Low levels of education (47.3\% had only primary or no education) necessitated training for increased fruit profitability.

As for factors linked to the operation of the market business, the profitability of the fruits sold was influenced by (a) method of acquisition (own production resulted in more profit than procurement from other sources); (b) expenditure on fruit (increased spending resulted in loss of profit); (c) fruit storage (increased storage resulted in loss of profit), and (d) cooperative approach (associated with increased profit). Highly significant positive correlations $(p<0.01)$ were noted between pairs of some of the factors, e.g. fruit own produced and fruit wastage, and highly significant negative correlations $(\mathrm{p}<0.01)$ were noted between pairs of other factors, e.g. cooperative approach and fruit own produced.

\section{References}

Baiphethi, M. N., \& Jacobs, P. T. (2009). The contribution of subsistence farming to food security in South Africa. Agrekon, 48(4), 459-482. http://dx.doi.org/10.1080/03031853.2009.9523836

Bembridge, T. J., \& Tshikolomo, K. A. (1998). Communication and decision making among fruit growers in the Phaswana Area of Northern Province. South African Journal of Agricultural Extension, 27, 19-29.

Bembridge, T. J., Graven, E. H., Hough, M. A., \& Van Rooyen, C. J. (1982). An evaluation of the Sheila and Mooifontein projects of Ditsobotla District of Bophuthatswana. Department of Agricultural Extension and Rural Development. University of Fort Hare, South Africa.

Crouch, B. R., \& Chamala, S. (1981). Extension education and rural development: experience in strategies for planned change. Department of Agriculture, John Wiley. University of Queensland, Australia.

Dagada, M. C., Nesamvuni, A. E., Van Rooyen, J., \& Tshikolomo, K. A. (2013). Operator Characterization and Acquisition of Sold Items for Tshakhuma and Khumbe markets of Limpopo Province, South Africa. International Journal of Business and Social Science, 4(8), 181-190.

Food and Agriculture Organization of the United Nations (FAO). (2001). The state of food and agriculture. United Nations, Rome, Italy.

Goodman, N., \& Marx, G. T. (1978). Society today (3rd ed.). Randon House, New York.

Hurmerinta-Peltomaki, L., \& Nummela, N. (2006). Mixed Methods in International Business Research: A Value-Added Perspective. Management International Review, 46(4), 439-459. $\mathrm{http}: / / \mathrm{dx}$. doi.org/10.1007/s11575-006-0100-z

IFAD. (2003). Promoting market access for the rural poor in order to achieve the Millennium Development Goals Rome. Discussion Paper, International Fund for Agricultural Development, Rome. Retrieved April 15, 2015, from http://www.ifad.org/gbdocs/gc/26/e/ markets.pdf

Kwaw, I. L. (2006). The Challenges Facing Organised Community Agricultural Projects to Alleviate Income Poverty in South Africa: The Case of Limpopo Province. Africa Insight, 36(2).

Leedy, P. D., \& Ormrod, J. E. (2010). Practical research, planning and design (8th ed.). Pearson Merrill Prentice Hall, New Jersey, USA.

Limpopo Department of Agriculture (LDA). (2014). GIS Map Production. Polokwane, Limpopo Province, South Africa. 
Lyne, M. C. (1996). Transforming developing agriculture: Establishing a basis for growth. Agrekon, 35(4), 188-192. http://dx.doi.org/10.1080/03031853.1996.9524833

Makhura, M. T., \& Mokoena, M. R. (2003). Market access for small-scale farmers in South Africa. In Nieuwoudt \& Groenewald (Eds.), The challenge of change, agriculture, land and the South African Economy. University of Natal Press, Pietermaritzburg.

Matungul, P. M., Lyne, M. C., \& Ortmann, G. F. (2001). Transaction costs and crop marketing in the communal areas of Impendle and Swayimana, KwaZulu-Natal. Development Southern Africa, 18(3), $347-363$. http://dx.doi.org/10.1080/03768350120070017

Mwale, M., Sarfo-Mensah, P., Zwane, E. M., Netshandama, V. O., \& Mudau, M. J. (2012). Marketability and Sustainability of Food Security Programmes: Products and Productivity of Agricultural Projects. South African Journal for Agricultural Extension, 40, 1-15.

Ndegwe, P., Mureithi, L. P., \& Green, R. H. (Eds.). (1985). Development Options for Africa in the 1980's and beyond. Oxford University Press with the Association of the Society for International Development, Nairobi, Kenya.

Office of the Premier (OTP). (2009). Limpopo Employment Growth and Development Plan. Polokwane, South Africa.

Olaiton, S. O. (1984). Agricultural education in the tropics: Methodology for teaching agriculture. Macmillan Intermediate Agricultural Series. New York, United States of America

Ortmann, G. F., \& King, R. P. (2007). Agricultural cooperatives II: Can they facilitate access of small-scale farmers in South Africa to input and product markets? Agrekon, 46(2). http://dx.doi.org/10.1080/03031853.2007.9523769

Tompson, A. R. (1981). Education and development in Africa. MacMillan Education, Ltd. London, Britain.

Tshikolomo, K. A., Nesamvuni, A. E., Stroebel, A., \& Walker, S. (2012). Water Supply and Requirements of Households in the Luvuvhu-Letaba Water Management Area of South Africa. International Journal of Business and Social Science, 3(3), 37-49.

van der Heijden, T., \& Vink, N. (2013). Good for Whom? Supermarkets and Small Farmers in South Africa - A Critical Review of Current Approaches to Increasing Access to Modern Markets. Agrekon, 52(1). http://dx.doi.org/10.1080/03031853.2013. 778466

Vermaak, N. J. (2014). The Thohoyandou Informal Market and Integrated Development. Journal of Public Administration, 49(4).

Welman, C., Kruger, F., \& Mitchell, B. (2005). Research methodology (3rd ed.). Oxford University Press, Cape Town, South Africa.

Williams, J. L. H. (1986). An evaluation of Training and Visit ( $T$ and $V$ ) extension programme in the Keiskamahoek District of Ciskei. Department of Agricultural Extension and Rural Development, University of Fort Hare, Eastern Cape, South Africa.

\section{Copyrights}

Copyright for this article is retained by the author(s), with first publication rights granted to the journal.

This is an open-access article distributed under the terms and conditions of the Creative Commons Attribution license (http://creativecommons.org/licenses/by/3.0/). 